J. Appl. Glycosci., 55, 235-244 (2008)

(C) 2008 The Japanese Society of Applied Glycoscience

Regular Paper (in Japanese with English Abstract)

\title{
Rheological Properties of Gelatinized Several Pastes from Stein-Hall Type Corrugating Starch Adhesives at High Temperature
}

(Received January 9, 2008; Accepted June 18, 2008)

\author{
Takatoshi Koyakumaru ${ }^{1, *}$ \\ Central Laboratory, Rengo Co., Ltd. \\ (4-1-186, Ohiraki, Fukushima-ku, Osaka 553-0007, Japan)
}

\begin{abstract}
This study was investigated the rheological properties of Stein-Hall type corrugating adhesives (SHadhesives) composed of carrier and main portions, which were needed for enhancing initial bond (green bond) strength to make the corrugated fiberboard at high speed on the double backer. Starch slurries and main portions of $\mathrm{SH}$-adhesives were individually prepared from each starch: corn, high-amylose maize (hylon-5), waxy maize, wheat, potato, sweet-potato and tapioca. All carrier portions were prepared from cooked corn starch paste only. Initial shear rigidity, maximum shear stress, shear stress-strain pattern and viscosity of these gelatinized pastes from slurries and $\mathrm{SH}$-adhesives were measured by the Couett type viscometer at $85^{\circ} \mathrm{C}$. The properties of those $\mathrm{SH}$-adhesives pastes depended on those of their main portions pastes, and were enhanced by their carrier portions. Rigidity and maximum stress of SH-adhesives pastes were varied by starch species, and these properties of the pastes from slurries increased as similar exponential function with increasing starch concentration in each species. So, these species pastes were organized into 4 types as type-1 of hylon-5, and type-2 of corn and wheat, and type-3 of potato, sweet potato and tapioca, and type-4 of waxy in order of the rigidity size and reverse order of strain size at maximum stress. And then, the rigidity was thought to be higher in the paste remaining the more clear shape gelatinized granules. Whereas, 7 kinds of SH-adhesive made a little difference in the green bond strength measured by table test. These results suggested that the rigidity and maximum stress were not most important factors in the rheological properties of gelatinized SH-adhesives pastes which were required to enhance the green bond strength on the corrugator.
\end{abstract}

Key words: corrugator, corrugated fiberboard, SH-adhesive, rheological property, green bond, glue line SEM

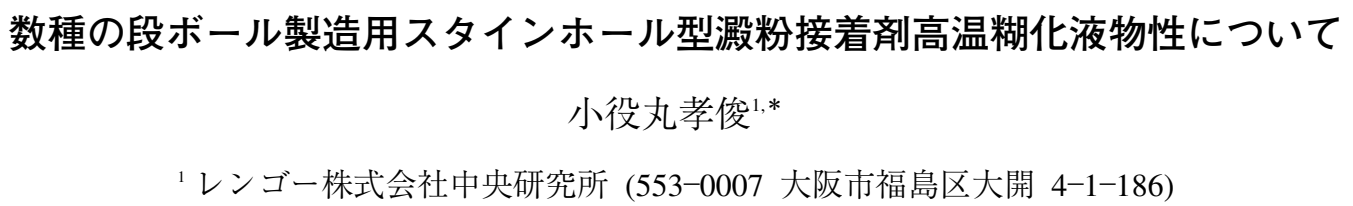

世界的に段ボールの生産量は，近年ますます増大してい く傾向にあり，国内においても段ボールシート製造用の接 着剂としての澱粉は，年間 13 万トン近く ${ }^{1)}$ 使用されてい る。また，段ボールシートの製造速度は飛躍的に向上して きており，最高製造速度は今や $400 \mathrm{~m} /$ 分をも超えようと している。この段ボールの製造最高速度は，澱粉接着剂の 性能に左右されていると言っても過言ではない.

本報告では，段ボールシート製造用澱粉接着剂として， 糊化澱粉水溶液 (キャリヤー部) と未糊化澱粉懸濁液 (メ イン部) とを混合して調製するいわゆるスタインホール型 (SH) 澱粉接着剂 (以後 SH 接着郕) ${ }^{2-5}$ を対象とした。 SH 接 着剂は，その未糊化懸濁澱粉粒を接着時の加熱により初め て急速に澎潤糊化させるところに最大の特徴があり，糊化 促進のためのアルカリとして苛性ソーダが多用されてい る. SH 接着剤は段ボールシート製造速度や操業性の向上

\footnotetext{
${ }^{*}$ Corresponding author (Tel. \& Fax. +81-6-6419-5901; E-mail: qq 648st9@ blue.ocn.ne.jp).
}

に必須な条件である高澱粉濃度で低粘度の接着剂が調製で きることから広く段ボールシート製造業で使用されてい る。しかしながら，この SH 接着剤について，その接着機 能に対するキャリヤー部澱粉の役割とメイン部澱粉の役割 や寄与についての解明は，いまだ段ボール業界での課題と なっている ${ }^{6-9)}$. さらに段ボールシート製造の生産性に関わ る初期接着力の向上と澱粉の性質との関係についての研究 は，キャリヤー部澱粉メイン部澱粉共にわずかに報告 ${ }^{10-12}$ があるが，体系化には至っていない。

Williams et al. によるとキャリヤー部澱粉水溶液は，単 なるメイン部澱粉の沈降防止や被接着体への塗布性能を向 上するだけでなく，フィルム強度の高いハイアミロース コーンスターチをキャリヤー部に使用すると初期接着性が 高くなり, 乾燥後の最終接着強度も向上するとし, キャリ

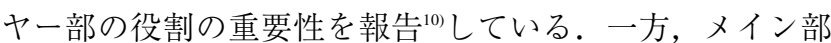

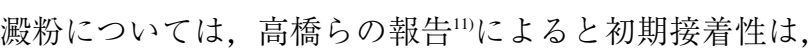
ブラベンダーアミログラフでの糊化開始から糊化までの見 掛けの膨潤速度の速いものが良好としている。このために 
は澱粉粒が適度に強く, 全澱粉が均一に膨潤する必要があ るとしている。また，Reinholzは，糊化時の粘度増加の大

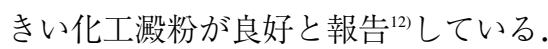

現在, 段ボール業界で多用されている SH 接着剤は, 澱 粉濃度 $25 \%$ 程度を中心として 20-34\% の高濃度状態で利 用されており，メイン部澱粉が加熱により糊化すると流動 性の少ない高粘度のゲル状を呈する。本報告では高速接着 時にメイン部澱粉が持つべき特性を検討するために，7 種 の澱粉を用いたメイン部相当の懸濁液と, さらにはこれら 澱粉をメイン部澱粉としてキャリヤー部糊化澱粉水溶液を 加えた SH 接着剂とを調製し，これらを糊化し，高温度下 で糊化液のレオロジー特性を比較した。ささらに加えてこれ ら 7 種澱粉 SH 接着剂についてテーブルテストでの初期接 着性と接着部の走査電子顕微鏡観察とを対比して検討を加 えたので報告する．

\section{実験材料と方法}

\section{1. 実 験 材 料}

普通トウモロコシ澱粉, 餅トウモロコシ澱粉, タピオカ 澱粉, (旧豊年製油株)提供品, 以下, トウモロコシ, ワキ シー, タピオカ), ハイアミローストウモロコシ澱粉 (旧 王子ナショナル(株)提供アミロース含量 $54 \%$ 品, 以下, 八 イロン-5), 小麦澱粉 (三和澱粉(株)提供品, 以下, 小麦), 馬鈴薯澱粉, 甘藷澱粉 (王子コーンスターチ(株)提供品, 以 下，馬鈴薯，甘墸) の 7 種の澱粉を用いた。

\section{2. 測定方法}

\section{1 ) レオロジーの測定}

実際のダブルフェーサー出口での接着剤部温度は, コル ゲーターの生産速度と加熱設備により大きく異なるが，温 度測定ラベル (帝国インキ製造(株)製)によると, 少なくと も $85^{\circ} \mathrm{C}$ 以上には加熱されていることがわかった。このた め SH 接着剤の加熱貼合時の温度条件に近い $85 \pm 1{ }^{\circ} \mathrm{C}$ の温 度で, 各種澱粉の澱粉懸濁液ならびに SH 接着剂の糊化液 のせん断応力, 粘度ならびに初期せん断弾性率を二重円筒 型 (Couette) 外筒回転式粘度計 (岩本製作所製 Rheometer IR) にて測定算出した。初期せん断弾性率は，せん断ひず み初期のせん断応力勾配より算出した. Rheometer IR での 測定条件は以下のとおりである。外筒内半径 $\left(r_{\mathrm{c}}\right), 11$ $\mathrm{mm}$; 内筒半径 $(r \mathrm{~b}), 8 \mathrm{~mm}$; 内筒浸液長 $(h), 71 \mathrm{~mm}$; 測 定液量, $20 \mathrm{~mL}$; 装置定数 $\left(A_{0}\right), 8.247 \times 10^{-3}$; せん断試料 厚さ $(d), d=r_{\mathrm{c}}-r_{\mathrm{b}}=3 \mathrm{~mm}$; 内筒角変位出力 $(V)$; 内筒角変 位量 $(\theta), 1 / 5 \times V \operatorname{deg}$; 回転数/分 $(N), 0.5 \mathrm{rpm}$; トーショ ンワイヤー定数 $(K), 9.251 \times 10^{5} \mathrm{dyn} \cdot \mathrm{cm} / \mathrm{deg}$; トルク $(T)$, $K \times \theta \mathrm{dyn} \cdot \mathrm{cm}$; せん断ひずみ速度 $(D), 2 r_{\mathrm{c}}^{2} \times N /\left[\left(r_{\mathrm{c}}{ }^{2}-r_{\mathrm{b}}{ }^{2}\right) \times\right.$ $9.55]=0.222 \mathrm{~s}^{-1}$; せん断応力 $\left(S_{\mathrm{i}}\right), T / 2 \pi h \mathrm{rb}^{2}=0.6478 \times V \mathrm{kPa}$; 粘度 $(\eta), S_{\mathrm{i}} / D=9.55 \times A_{0} \times T / N=2.9144 \times V \mathrm{kPa} \cdot \mathrm{s}$; ひずみ量 $(\Delta l / d)), \Delta l / d=2 \pi r_{c} \times 6 \mathrm{~N} / 360 \cdot \mathrm{s}^{-1} \div d=0.192 / \mathrm{s}$; 初期せん断 弾性率 $(G), S_{\mathrm{i}} /(\Delta l / d)$.
2 ) 糊化温度の測定

澱粉懸濁液ならびに SH 接着剂の糊化温度は，ブラベン ダー社のビスコグラフで測定した。測定容器に澱粉懸濁液 (澱粉濃度 $25 \%$ ) ならびに接着剤液 (澱粉濃度 27\%) 450 $\mathrm{mL}$ を入れ, 容器を $75 \mathrm{rpm}$ で回転させながら $40^{\circ} \mathrm{C}$ から毎 分 $1.5^{\circ} \mathrm{C}$ の昇温速度で加温して粘度变化を測定した。粘度 が最低粘度から $20 \mathrm{BU}$ (ブラベンダーユニット) 上昇した 温度を糊化開始温度, $1000 \mathrm{BU}$ に達した温度を糊化温度と した。翼はパドルタイプを使用した。

3 ) 段ボール貼合時の初期接着性テーブル試験およびピ ン接着強度測定

初期接着性テーブル試験は，7 種澱粉を各々メイン澱粉 とし，キャリヤー部澱粉は全て糊化普通トウモロコシ澱粉 水溶液に限定して調製した 7 種澱粉の SH 型接着剤につい て，テーブルテストにて片段 (幅 $50 \mathrm{~mm} \times$ 流れ $80 \mathrm{~mm}$ ) に 接着剂液を乾量換算で $4.5 \mathrm{~g} / \mathrm{m}^{2}$ 塗布し, 同一寸法のライ ナーの裏面と合せてライナー表面側から $2.45 \mathrm{kPa}$ の圧力で 所定時間 $170^{\circ} \mathrm{C}$ 加熱プレートにて加熱貼合し，ただちに剥 離して初期接着性を 7 段階で評価した。片段は AF (段高 さ $5 \mathrm{~mm}$, 段数 $34 \pm 2 / 300 \mathrm{~mm}$ ) で裏ライナーB-220 (旧 JISP-3902 の B 級 ライナー), 中芯 SCP-125 (Semi-Chemical Pulp corrugating medium $\left.125 \mathrm{~g} / \mathrm{m}^{2}\right)$ のものを, 表ライナー にはB-300 (旧 JIS, B 級 $300 \mathrm{~g} / \mathrm{m}^{2}$, 厚さ $0.399 \mathrm{~mm}$, 密度 0.784 , 裏コッブ 2 分吸水度 $40 \mathrm{~g} / \mathrm{m}^{2}$ ) を貼合せに用いた. 加熱条件は実際のコルゲーターのダブルフェーサーでの加 熱温度と時間に近い $170^{\circ} \mathrm{C}$ で 3-5 秒間とした。初期接着性 (Green bond index) の評価は, 所定時間加熱後，ただちに 剥離したときの糊線部 (グルーライン) の材破率により 7 段階基準で行った。 7，100\% 材破；6，90\%材破；5，7080\% 材破；4，50-60\% 材破；3，20-30\%材破；2，わずか に毛羽立ち；1, 材破無し.ちなみにコルゲーターのダブル フェーサーカッター先にて強制剥離した際に初期接着性レ ベルが 3.5 以上 (ライナー側糊線部材破率 $40 \%$ 以上) あれ ば罫線加工や裁断加工に伴う応力に耐え, 罫線部や裁断部 での接着剥がれは生じないと経験上判断される.また, 同一 時間加熱貼合した未剥離サンプルについては，温度 $20^{\circ} \mathrm{C}$, 相対湿度 $65 \%$ RH下で平衡水分に達するまで調湿後, 旧 JIS-Z-0402に準じて (幅 $50 \mathrm{~mm} \times$ 流れ $80 \mathrm{~mm}$, 片面剥離) ピ ン接着強度を測定した。

4 ) 接着剂凝集破壊部の走査電子顕微鏡観察

上記初期接着性の評価のために強制剥離した片段と表ラ イナーの接着剤凝集破壊部を金でスパッタリング蒸着して 走査電子顕微鏡 $($ SEM : 日本電子(株)製 JSM-5400 LV) にて 観察した。

\section{結果および考察}

\section{1. 澱粉懸濁液糊化液と SH 接着剤糊化液の物性比較}

所定の苛性ソーダ濃度の水溶液にハイロン -5, トゥモロ コシ, 甘諸, タピオカ, ワキシー, 小麦, 馬鈴薯の 7 種の 
Table 1. Rheological properties of gelatinized 7 starch pastes from slurries and SH-adhesives at $85^{\circ} \mathrm{C}$.

\begin{tabular}{|c|c|c|c|c|c|c|c|c|}
\hline Main portion starch & & Corn & Wheat & Hylon-5 & Waxy & Potato & Sweet potato & Tapioca \\
\hline $\mathrm{NaOH}$ conc. $(\%)$ in water & & 0.50 & 0.40 & 0.75 & 0.50 & 0.40 & 0.50 & 0.50 \\
\hline \multirow{2}{*}{$\begin{array}{l}\text { Gelatinization temp. } \\
\text { at } 20 \mathrm{BU}\left({ }^{\circ} \mathrm{C}\right)\end{array}$} & Adhesive & 65.5 & 52.5 & 59.5 & 55.8 & 52.9 & \multirow[t]{2}{*}{61.8} & \multirow[t]{2}{*}{59.5} \\
\hline & Slurry & 64.0 & 55.0 & 56.3 & 61.3 & 52.8 & & \\
\hline \multirow{2}{*}{$\begin{array}{l}\text { Gelatinization temp. } \\
\text { at } 1000 \mathrm{BU}\left({ }^{\circ} \mathrm{C}\right)\end{array}$} & Adhesive & 68.2 & 57.2 & 62.4 & 62.1 & 57.0 & \multirow[t]{2}{*}{65.5} & \multirow[t]{2}{*}{63.1} \\
\hline & Slurry & 65.5 & 57.0 & 60.0 & 65.0 & 55.7 & & \\
\hline \multirow{2}{*}{$\begin{array}{l}\text { Brookfield viscosity of } \\
\text { SH-adhesive at } 40^{\circ} \mathrm{C}(\mathrm{mPa} \cdot \mathrm{s})\end{array}$} & Make up & 360 & 380 & 300 & \multirow[t]{2}{*}{1430} & 400 & 185 & 240 \\
\hline & After $1 \mathrm{~h}$ & 350 & 325 & 280 & & 325 & 170 & 210 \\
\hline \multirow{2}{*}{ Shear rigidity $(\mathrm{kPa})$} & Paste of adhesive & 2.28 & 1.10 & 5.40 & 0.22 & 1.69 & 0.88 & 0.57 \\
\hline & Paste of slurry & 1.27 & 0.89 & 5.23 & 0.14 & 1.07 & 0.59 & 0.37 \\
\hline \multirow{2}{*}{ Stress peak $(\mathrm{kPa})$} & Paste of adhesive & 2.97 & 1.51 & 2.07 & 1.08 & 4.96 & 2.01 & 1.77 \\
\hline & Paste of slurry & 1.24 & 0.93 & 2.40 & 0.69 & 4.59 & 1.68 & 1.19 \\
\hline \multirow{2}{*}{$\begin{array}{l}\text { Shear strain } \\
\text { at stress peak }(\Delta l / d)\end{array}$} & Paste of adhesive & 2.30 & 2.11 & 0.96 & 10.75 & 7.30 & 3.84 & 7.30 \\
\hline & Paste of slurry & 1.73 & 1.92 & 0.58 & 10.37 & 5.76 & 4.99 & 6.91 \\
\hline \multirow{2}{*}{ Stress strain pattern } & Paste of adhesive & B & B & A & $\mathrm{C}$ & B & B & B \\
\hline & Paste of slurry & B & B & A & $\mathrm{C}$ & B & B & B \\
\hline \multirow{2}{*}{ Viscosity $(\mathrm{kPa} \cdot \mathrm{s})$} & Paste of adhesive & 11.7 & 5.8 & 8.5 & 4.8 & 22.2 & 8.7 & 7.9 \\
\hline & Paste of slurry & 5.3 & 4.1 & 8.0 & 3.1 & 18.5 & 7.6 & 5.3 \\
\hline
\end{tabular}

澱粉を各々分散し,さらに硼砂 $\left(\mathrm{Na}_{2} \mathrm{~B}_{4} \mathrm{O}_{7} \cdot 10 \mathrm{H}_{2} \mathrm{O}\right)$ をそれ ぞれ対澱粉 $2.3 \%$ 添加して，3 倍水 (全水/全澱粉) SH 接着 剂のメイン部相当の澱粉濃度 $25 \%$ 懸濁液を調製した。ま た, 次に 7 種メイン部澱粉懸濁液に, 普通トウモロコシ澱 粉の苛性ソーダ添加加熱擋拌糊化水溶液をキャリヤー部と して添加して, 各種澱粉をメイン部澱粉とするトータル澱 粉濃度 $27 \%$ の 2.7 倍水 7 種澱粉 SH 接着剂を調製した. 各 $\mathrm{SH}$ 接着剂ではキャリヤー部糊化澱粉水溶液を, 澱粉固形 分として各種メイン部澱粉固形分 9 部 (24.3\%) に対して 1 部 $(2.7 \%)$ の量比で添加した。従って各 SH 接着剤には懸 濁液の場合と同量の水量に同量の苛性ソーダと各種メイン 部澱粉と, 新たにメイン部澱粉の $11.1 \%$ に相当するトウ モロコシ澱粉がキャリヤー部として加わって溶け込んでい る状態となる。

ここで，段ボール製造用 SH 接着剂は，接着貼合速度の アップと温度粘度変化を防ぐために貯蔵槽とコルゲーター との間を循環させながら通常 $40^{\circ} \mathrm{C}$ に保温して使用する. この際, SH 接着剂の大部分を占める未糊化澱粉の糊化温 度を下げるために添加している苛性ソーダ濃度が高いと, 使用時に澱粉が徐々に膨潤して増粘する。従って，本実験 での苛性ソーダ濃度は, 澱粉濃度 $27 \%$ で 7 種澱粉が $\mathrm{SH}$ 接着剂に調製された際に，接着剂(キャリヤー澱粉比率 $11.1 \%)$ 粘度が経時的に大きく増粘や減粘を起こさないよ うに考慮して 7 種澱粉に応じて変え, Table 1 に示すよう にハイロン -5 は対水苛性ソーダ濃度で $0.75 \%$, トウモロコ シ, 甘諸, タピオカ, ワキシーは $0.5 \%$, 小麦と馬鈴薯は $0.4 \%$ に調製した。それぞれの SH 接着剤の糊化開始温度 と糊化温度は, ハイロン $-5\left(59.5^{\circ} \mathrm{C}, 62.4^{\circ} \mathrm{C}\right)$, トゥモロコシ $\left(65.5^{\circ} \mathrm{C}, 68.2^{\circ} \mathrm{C}\right)$, 甘藷 $\left(61.8^{\circ} \mathrm{C}, 65.5^{\circ} \mathrm{C}\right)$, 夕ピオカ $\left(59.5^{\circ} \mathrm{C}\right.$, $\left.63.1^{\circ} \mathrm{C}\right)$, ワキシー $\left(55.8^{\circ} \mathrm{C}, 62.1^{\circ} \mathrm{C}\right)$, 小麦 $\left(52.5^{\circ} \mathrm{C}, 57.2^{\circ} \mathrm{C}\right)$, 馬鈴薯 $\left(52.9^{\circ} \mathrm{C}, 57.0^{\circ} \mathrm{C}\right)$ であった。澱粉濃度 $25 \%$ の各懸
濁液についても同じ苛性ソーダ濃度とした．SH 接着剂調 製時の出来上がり $40^{\circ} \mathrm{C}$ でのブルックフィールド粘度計粘 度と経時 1 時間後の同粘度とを合せて Table 1 に示した。

これらの澱粉懸濁液ならびに SH 接着剤を所定量糊化液 物性測定用円筒容器に入れ, Rheometer IRに装備された $85^{\circ} \mathrm{C}$ のオイルバス内で本円筒をゆっくりと回しながら加 熱し，わずかに増粘を始めた時点で回転を止め, 澱粉懸濁 液が $85^{\circ} \mathrm{C}$ になるまで約 30 分間加熱を続けて糊化した。次 に澱粉糊化液を装填した円筒をクラッチ操作で瞬時に接続

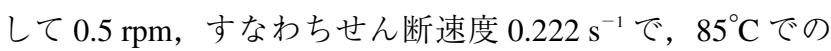
糊化液のせん断ひずみ初期のせん断弾性率 (以下, 弾性 率) とせん断応力值と粘度を測定した.

7 種澱粉懸濁液加熱糊化液の $85^{\circ} \mathrm{C}$ でのせん断ひずみと 応力とのせん断応力パターンは Fig. 1(a)に示すように澱粉 種により大きく異なった. ハイロン -5 ではひずみ量 0.58 のひずみ初期に顕著な応力ピークを形成するせん断応力パ

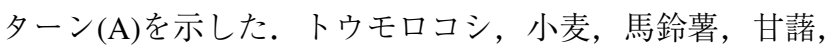
タピオカでは全てひずみ量の増加と共にしだいに応力值が 増加するせん断応力パターン $(\mathrm{B})$ を示した。 ワキシーでは, 応力值がひずみ量 9 以上にまで $\mathrm{S}$ 字状に徐々に高くなる せん断応力パターン $(\mathrm{C})$ を示した.

Table 1 に示すように 7 種澱粉懸濁液糊化液の $85^{\circ} \mathrm{C}$ での 弾性率は, 実験を行った澱粉種の中では, 苛性ソーダ濃度 $0.75 \%$ のハイロン -5 が最も高く, 次いでトウモロコシ, 馬 鈴薯, 小麦, 甘藷, 夕ピオカの順となり, ワキシーが最も 低かった。一方, 最大応力值は, Fig. 1(a)と Table 1 に示 すように馬鈴薯が最も高く, ハイロン -5 , 甘諸, トウモロ コシ, タピオカ, 小麦, ワキシーの順序に低くなった。次 に 7 種澱粉メイン部使用 $27 \%$ 澱粉濃度の SH 接着剂糊化 液の弾性率は, 同じく Table 1 と Fig. 1(b)に示すように7 種澱粉 $25 \%$ 懸濁液糊化液の弾性率を強く反映し, 八イロ 

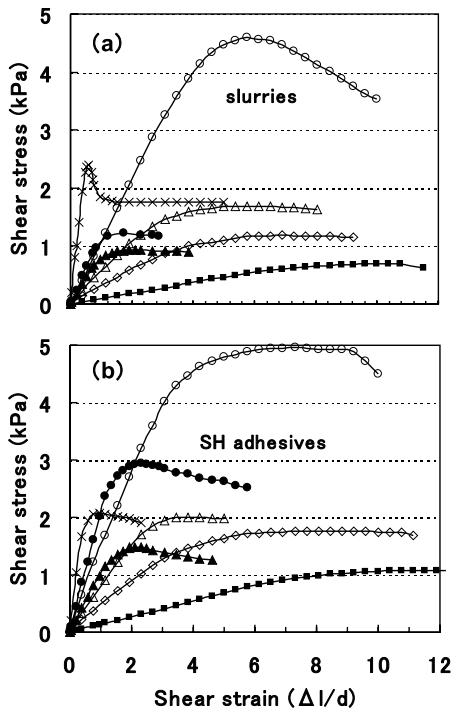

Fig. 1. Shear stress-strain pattern of the starch pastes at $85^{\circ} \mathrm{C}$ from slurries and $\mathrm{SH}$-adhesives.

(a), Slurries; (b), SH-adhesives. $\times$, Hylon-5 $\mathrm{NaOH} 0.75 \%$; Corn $\mathrm{NaOH} 0.5 \%$; $\boldsymbol{\Delta}$, Wheat $\mathrm{NaOH} 0.4 \%$; $\mathbf{\square}$, Waxy $\mathrm{NaOH} 0.5 \%$; $\bigcirc$, Potato $\mathrm{NaOH} 0.4 \%$; $\triangle$, Sweet potato $\mathrm{NaOH} 0.5 \%$; $\diamond$, Tapioca $\mathrm{NaOH} 0.5 \%$.

ン -5 が最も高く, トウモロコシ, 馬鈴薯, 小麦, 甘藷, 夕ピオカ, ワキシーの順で, 澱粉懸濁液糊化液と同順で あった。 全体としては, Table 1 に示すようにキャリヤー 部トウモロコシ糊化澱粉水溶液の添加により弾性率が高く なり，膨潤澱粉粒間の結合力の増強効果がみられた。最大 応力值についてはトウモロコシでは 7 種澱粉懸濁液糊化液 の大きさの順序と異なって高くなったが，その他の澱粉で は同じ順序となり，馬鈴薯，トウモロコシ，八イロン -5, 甘藷, タピオカ, 小麦, ワキシーの順となった。 ハイロン -5 では鋭い応力ピークはなくなったが, 澱粉懸濁液糊化液と 同様にひずみ量 0.96 のひずみ初期に最大応力值に達し, 全体として接着剂糊化液のせん断応力パターンは，澱粉懸 濁液糊化液のパターンを強く反映した。 また, Fig. 1 に示 すせん断応力ピーク後のやや落ち着いた応力值やほほ平衡 に達した応力值から概算した粘度とみなした值は, Table 1 に示すように SH 接着剂糊化液では, 懸濁液糊化 液の 1.1-2.2 倍に増加した。

キャリヤー部を加えた SH 接着剂では，キャリヤー部糊 化澱粉水溶液中に懸濁した未糊化澱粉粒が，加熱により キャリヤー澱粉水溶液中の水を吸水して糊化して膨潤粒と なる。

結果としてキャリヤー部澱粉は濃縮されて膨潤粒間に薄 膜状に残留して膨潤澱粉粒間の結合力を高め ${ }^{9,10)}$, せん断 弾性率が懸濁液糊化液に比べて 1-1.8倍に高くなると共 に，せん断ひずみによる膨潤澱粉粒間結合も崩れにくくな り, 大きなひずみ量まで応力が増加を続け, 最大せん断応 力值はハイロン -5 を除き 1.1-2.4 倍に高くなり粘度值も高 くなった。

\section{2. 糊化液物性に及ぼす澱粉濃度の影響}

SH 澱粉接着剂部はコルゲーターでの貼合時の加熱によ り糊化した後, 含有水分は原紙への吸収移行と蒸散とが進
み，接着剂糊化液は濃縮されて初期接着力が増加してい く.この過程の糊化液の物性変化を㝝うものとして，八イ ロン-5, トウモロコシ, 甘藷, タピオカ, ワキシー, 小 麦，馬鈴著の 7 種澱粉懸濁液糊化液について，各々澱粉濃

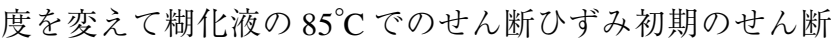
弾性率ならびに最大せん断応力值と粘度を測定した。苛性 ソーダ濃度は, 前項と同じく水に対する濃度でハイロン -5 は $0.75 \%$ ，トウモロコシ，甘諸，タピオカ，ワキシーは $0.5 \%$ ，小麦と馬鈴薯は $0.4 \%$ の濃度とした. 硼砂の添加率 も前項と同じく全て対澱粉 $2.3 \%$ にした。なお，各種澱粉 の澱粉濃度は段ボール業界では, SH 接着剤の澱粉濃度と して 25\% 程度を中心として 20-34\%の濃度で利用されて いることから，20\% (4 倍水) から 33.3-40\% (2-1.5 倍水) の範囲で 4-6 点測定した.

実験の結果 30 分間加熱後, 弾性率を測定した後の $85^{\circ} \mathrm{C}$ の高温糊化液においても, 目視でトウモロコシでは濃度 $28.6 \%$ (2.5 倍水) 以上で，ハイロン -5 では濃度 $33.3 \%(2$ 倍水) 以上で，ワキシーと小麦では濃度 $40 \%$ で不透明な 未糊化澱粉粒が一部にみられた。また，馬鈴薯では 20$40 \%$ までの全ての実験区で不透明な澱粉粒が一部にみら れた。甘藷では実験を行った $33.3 \%$ 以下では不透明な澱 粉粒はなく, 夕ピオカでは $33.3 \%$ 以上で不透明な澱粉粒 が一部にみられた。

20-40\% 濃度 (4-1.5 倍水) 範囲 7 種澱粉懸濁液の加熱糊 化液の $85^{\circ} \mathrm{C}$ での各澱粉濃度におけるせん断応力パターン はFig. 2 に示すように澱粉種により大きく異なった.

Fig. 2 と Fig. 3(a)に示すように，ハイロン-5では 20\%の低 い濃度でも高濃度の場合と同様，弾性率が $2.80 \mathrm{kPa}$ 以上と 高く, ひずみ量 0.46 に顕著な応力ピークを形成し, 全濃

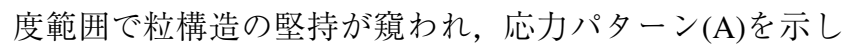
た。トウモロコシ，小麦，馬鈴薯，甘諸，タピオカでは全 てひずみ量の増加に従って応力值が増加し, 増加程度が少 ない種でもひずみ量 7 程度までに最大応力值に達し, 応力 パターン $(\mathrm{B})$ を示した. ワキシーでは $33.3 \%$ 濃度までせん 断弾性率は $0.56 \mathrm{kPa}$ 以下と低く, ひずみ初期の低い応力值 が徐々に S 字状にひずみ量の増加と共に増加し，ひずみ 量 9 以上にまで増加が続く応力パターン $(\mathrm{C})$ を示した.

Fig. 3(a)に示すように澱粉濃度 20\%の 7 種澱粉高濃度糊 化液の $85^{\circ} \mathrm{C}$ での弾性率は, 実験を行った澱粉種の中では, 苛性ソーダ濃度 $0.75 \%$ のハイロン -5 が最も高く, 次いで トウモロコシ, 馬鈴薯, 小麦, 甘藷, 夕ピオカの順とな り，ワキシーが最も低かった。各種澱粉共に澱粉濃度が $20 \%$ から増加していくと弾性率が著しく高くなり，澱粉 濃度 $28.6 \%$ 以上で小麦が馬鈴薯よりも高くなった以外は 順序も変わらずに高くなった．濃度 $33.3 \%$ ではワキシー 以外は $20 \%$ 時の 5-17 倍の $1 \mathrm{kPa}$ 以上となり，濃度 $40 \%$ で は 7-30 倍まで増加しハイロン-5 とトウモロコシでは, そ れぞれ 20.58，11.05 kPa に達した。ワキシーでは濃度 $40 \%$ で $2.36 \mathrm{kPa}$ であり $20 \%$ 時の約 44 倍とはなったが, 弾性率 自体の值は低くトウモロコシの $1 / 5$ 程度であった。このよ 

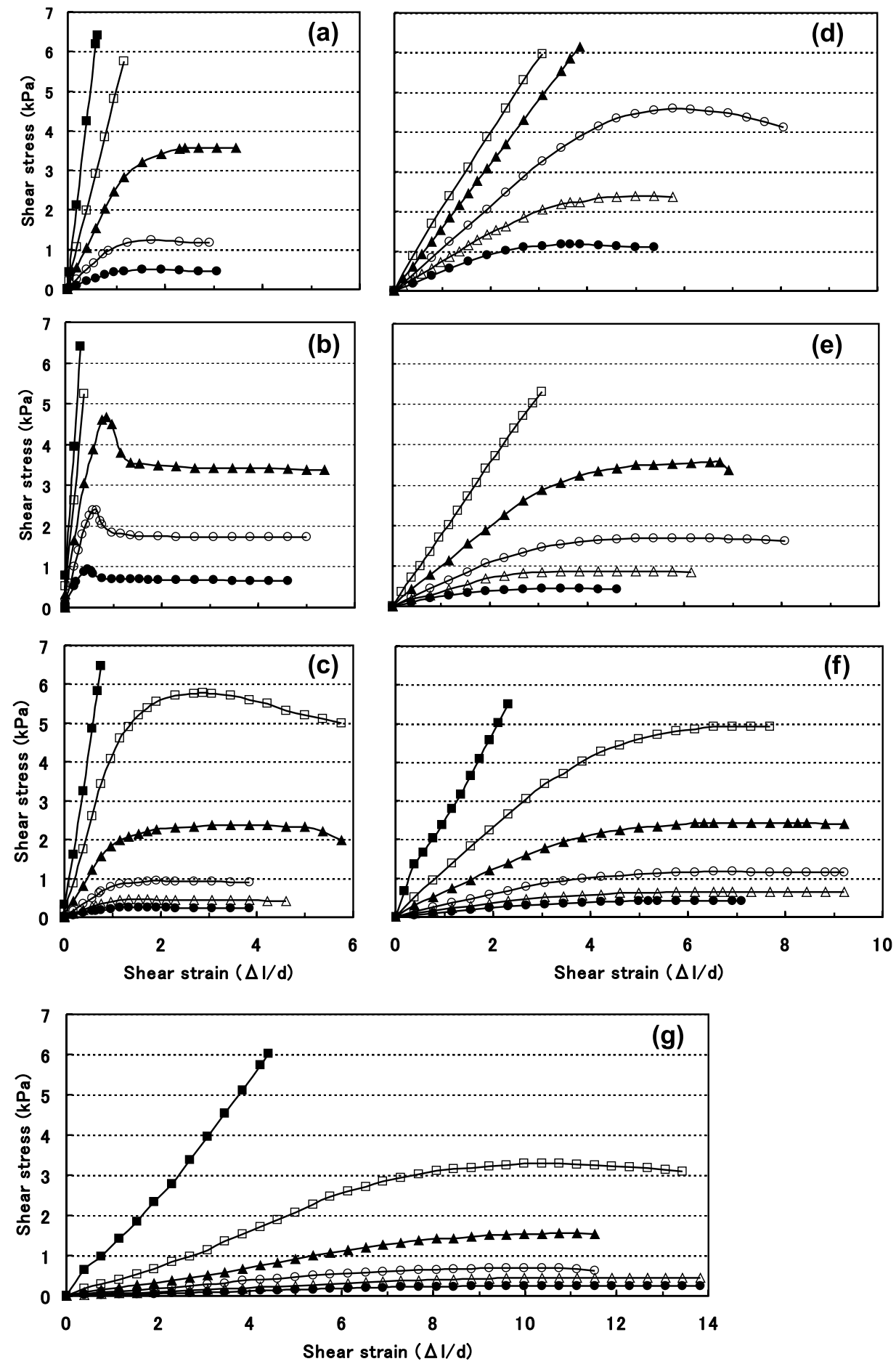

Fig. 2. The effect of starch concentration on the shear stress-strain pattern of 7 starch pastes at $85^{\circ} \mathrm{C}$ from slurries.

(a), Corn; (b), Hylon-5; (c), Wheat; (d), Potato; (e), Sweet potato; (f), Tapioca; (g), Waxy. Starch concentration: $\mathbf{\square}, 40 \%$; $\square, 33.3 \%$; $\mathbf{\Delta}$, $28.6 \% ; \bigcirc, 25 \% ; \triangle, 22.2 \% ; \bullet, 20 \%$.

うに弾性率は, ワキシーを除きハイロン-5, トウモロコ シ，小麦の地上澱粉で高く，地下澱粉で低い傾向にあっ た.また，Fig. 3(b)に示すように最大応力値も澱粉濃度の 増加により指数関数的に増加した. 全般として最大応力值 は，応力パターンは異なるが，ハイロン -5 と馬鈴薯で高 く, トウモロコシ, 甘藷, タピオカ, 小麦の順に低くな り，ワキシーが最も低くなった。測定装置の制約上最大せ ん断応力值については $7 \mathrm{kPa}$ 以上の測定はできないため, 澱粉濃度 $28.6 \%$ で 7 種の澱粉について各々に最大応力值 を比較した場合，それぞれ $20 \%$ 濃度時の 5-9 倍強に増加
した。最も值の高い馬鈴薯では $1.17 \mathrm{kPa}$ から $6 \mathrm{kPa}$ 以上 に，ハイロン-5では $0.95 \mathrm{kPa}$ から $4.66 \mathrm{kPa}$, トウモロコ シ, 甘藷, 小麦, 夕ピオカの 4 種では $0.25-0.48 \mathrm{kPa}$ から $2.37-3.63 \mathrm{kPa}$, 最も值の低いワキシーでは $0.25 \mathrm{kPa}$ から $1.54 \mathrm{kPa}$ となった。 また, Fig. 2 および Fig. 3(c)に示すよ うにせん断応力ピーク後のやや落ち着いた応力值やほほ平 衡に達した応力值から概算した粘度とみなした值も，馬鈴 薯が最も高く，次にハイロン -5 , トウモロコシ，甘藷，少 し低くなって小麦, タピオカ, さらに少し低くなってワキ シーの順であったが, いずれの澱粉種も $20 \%$ から 25- 

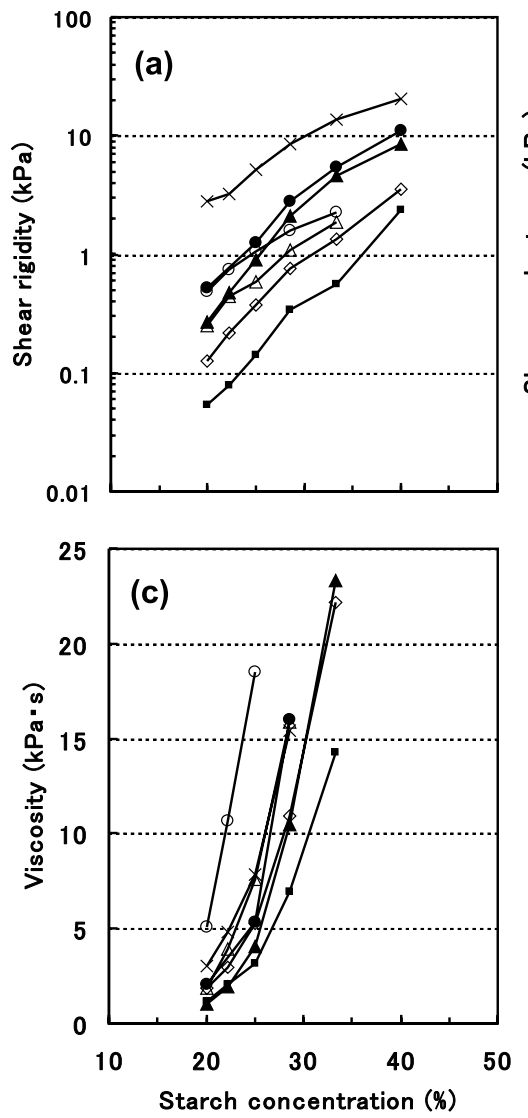

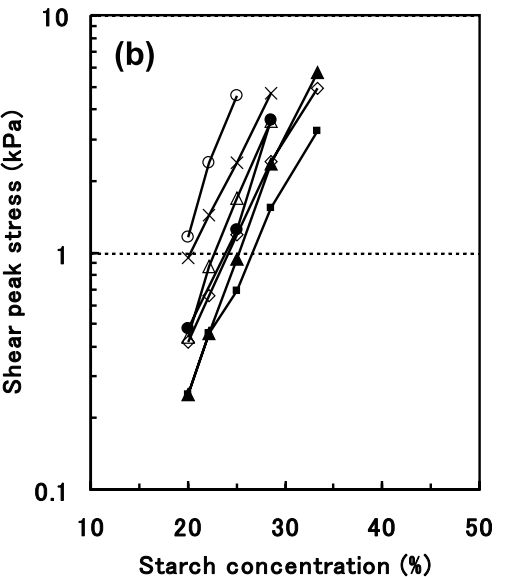

Starch concentration (\%)

Fig. 3. The effect of starch concentration on the rigidity, shear peak stress and viscosity of 7 starch pastes at $85^{\circ} \mathrm{C}$ from slurries.

(a), Shear rigidity; (b), Shear peak stress; (c), Viscosity. ×, Hylon-5; ๑, Corn; $\mathbf{\Delta}$, Wheat; $\mathbf{\square}$, Waxy; $\bigcirc$, Potato; $\triangle$, Sweet potato; $\diamond$, Tapioca.
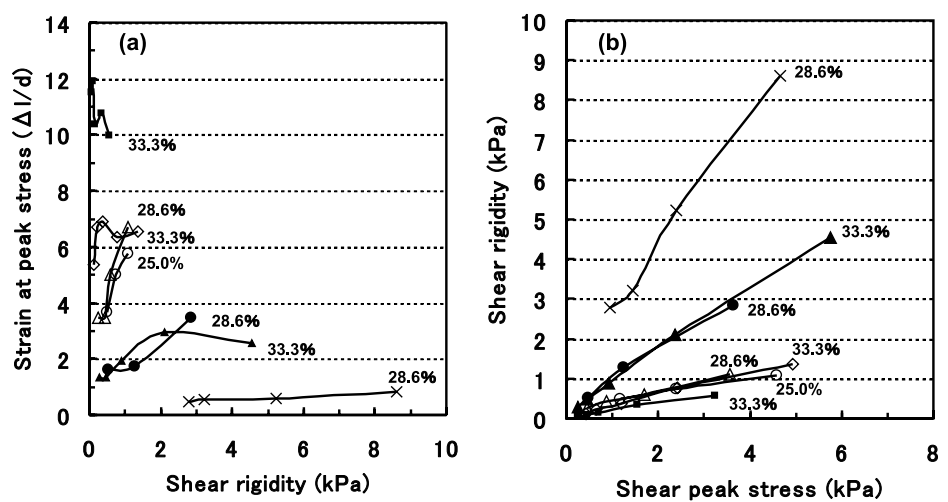

Fig. 4. Relation between rigidity, peak stress and strain at peak stress of 7 starch pastes at $85^{\circ} \mathrm{C}$ from slurries.

(a), Relation between shear rigidity and strain at peak stress; (b), Relation between shear peak stress and shear rigidity. $\times$, Hylon-5; $\boldsymbol{\bullet}$, Corn; $\Delta$, Wheat; $\mathbf{\square}$, Waxy; $\bigcirc$, Potato; $\triangle$, Sweet potato; $\diamond$, Tapioca.

$28.6 \%$ に澱粉濃度が増加すると粘度は 5-10 倍以上に急増 し，濃度増加による影響は著しかった。

所定の苛性ソーダ濃度で澱粉濃度を変えた 7 種の澱粉懸 濁液糊化液のレオロジー挙動を, Fig. 4(a)に示すように最 大応力までのひずみ量を縦軸とし，せん断弾性率を横軸と して二つのパラメータで整理すると，興味深いことに 7 種 の澱粉により澱粉濃度の増加による弾性率と最大応力ひず み量との変化は異なり四つのタイプに類別された。ただし 装置の制約上，最大応力ひずみ量が測定できた澱粉濃度 は，ワキシー，夕ピオカ，小麦が20-33.3\%，甘諸，トウ モロコシ，ハイロン -5 が20-28.6\%，馬鈴薯が 20-25\%で あった. Fig. 4(a)では, 7 種澱粉の測定最大濃度ポイント
に濃度值を図中に併記した。

その結果，それぞれ濃度が $20 \%$ から約 1.3-1.6 倍まで増 加した範囲において，ワキシーでは弾性率が $0.05-0.56 \mathrm{kPa}$ と低く，最大応力ひずみ量は 9.98-11.90 と大きくなり，反 対にハイロン -5 では弾性率が 2.80-8.61 kPa と高く, 最大 応力ひずみ量は 0.46-0.81 と少なくなった。馬鈴著・甘

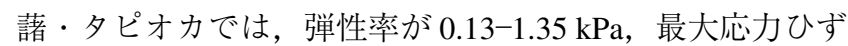
み量が 3.46-6.91, 小麦・トウモロコシでは弾性率が $0.27-$ $4.56 \mathrm{kPa}$ ，最大応力ひずみ量が 1.34-3.46 と，ワキシーとハ イロン -5の中間のレベルとなり明瞭に四つのタイプに類 別された。

さらに, Fig. 4(b)に示すように澱粉濃度の増加に従って 
Table 2. Green bond index and pin adhesion strength of the adhesion samples laminated with 7 starch SH-adhesives.

\begin{tabular}{|c|c|c|c|c|c|c|c|}
\hline \multirow[b]{3}{*}{ Main starch } & \multirow[b]{3}{*}{$\mathrm{NaOH}$ conc. in water $(\%)$} & \multicolumn{3}{|c|}{ Green bond index } & \multicolumn{3}{|c|}{ Pin adhesion strength $\left(\mathrm{kg} / 40 \mathrm{~cm}^{2}\right)$} \\
\hline & & \multicolumn{3}{|c|}{ Heating time with $170^{\circ} \mathrm{C}$ plate } & \multicolumn{3}{|c|}{ Heating time with $170^{\circ} \mathrm{C}$ plate } \\
\hline & & $3 \mathrm{~s}$ & $4 \mathrm{~s}$ & $5 \mathrm{~s}$ & $3 \mathrm{~s}$ & $4 \mathrm{~s}$ & $5 \mathrm{~s}$ \\
\hline Corn & 0.50 & 3.2 & 4.0 & 5.0 & 27.8 & & 25.8 \\
\hline Wheat & 0.40 & 3.0 & 3.5 & 5.0 & 26.7 & 25.7 & 25.3 \\
\hline Hylon-5 & 0.75 & 3.5 & 4.5 & 5.0 & 23.0 & 24.4 & 22.9 \\
\hline Waxy & 0.40 & 3.0 & 3.0 & 4.0 & 22.0 & 24.2 & 24.4 \\
\hline Potato & 0.40 & 3.0 & 4.0 & 4.5 & 26.0 & & 24.7 \\
\hline Sweet potato & 0.50 & 3.0 & 3.5 & 4.5 & 28.8 & & 30.1 \\
\hline Tapioca & 0.50 & 3.0 & 4.5 & 5.0 & 24.7 & & 23.3 \\
\hline
\end{tabular}

Main portion starch concentration, $24.3 \%$; carrier portion starch concentration, $2.7 \%$; borax $/$ starch, $2.3 \%$.

それぞれの澱粉種では弾性率と最大応力值はほぼ比例して 増大する関係にあったが，この関係においてもハイロン -5 と, 小麦・トゥモロコシと, 馬鈴薯・甘藷・タピオカと, ワキシーとの四つに類別され, 弾性率と最大応力值との関 係からも澱粉種により糊化液物性が異なることが示唆され た. Fig. 4(b)では 7 種澱粉の測定最大濃度ポイントに濃度 值を図中に併記した。

実際のコルゲーターダブルフェーサーでの段ボール製造 貼合時において，貼合される段ボールシート自体は走行し ているが，片段の中しん段頂部に塗布された SH 接着剤部 は，摚き混ぜられることなくスタティックにダブルフェー サーのスチーム加熱熱盤 $\left(170^{\circ} \mathrm{C}\right)$ にて表ライナー原紙を 介して加熱され, 糊化濃縮乾燥される。このため, 接着剤 は外力を受けることなく高濃度状態で糊化し, 接着剤糊化 液物性は澱粉種に由来する膨潤澱粉粒自体の強さや変形の し易さや崩壊流動性などの性質がそのままに反映すると考 えられた。すなわち使用される各種澱粉が, 粒構造の強い 八イロン-5, 次に粒構造が強くゲル性状のトウモロコシと 小麦, 膨潤粒形状の変形が容易な馬鈴薯, 甘藷, タピオ カ，ゾル性状の強いワキシーとそれぞれの特徵的な糊化液 性状を示すと考えられた。

これらのことから，コルゲーターでの加熱接着時には， SH 接着剂部は糊化後に原紙による吸水と加熱蒸散により 濃縮されるが, 初期接着完了後の接着剂部の応力による変 形性には澱粉種により相違が大きく, 比較的応力により変 形し易い澱粉種としにくい種とがあると考えられた.

\section{SH 接着剤の初期接着性テーブル試験}

7 種澱粉を SH 接着剂のメイン澱粉として使用し, キャ リヤー部澱粉は全て糊化普通トウモロコシ澱粉水溶液とし て, 第 1 項でせん断弾性率やせん断応力を測定した同じ配 合の 7 種 SH 接着剤について, 前記試験方法にてテーブル テストで初期接着性を 7 段階で評価した。また，同一時間 加熱貼合した未剥離サンプルについては， $20^{\circ} \mathrm{C}$ 相対湿度 (RH) $65 \%$ で 24 時間以上調湿後, 旧 JIS-Z-0402に準じて (幅 $50 \mathrm{~mm} \times$ 流れ $80 \mathrm{~mm}$, 片面剥離) ピン接着強度を測定し た。この結果を Table 2 に示す.

3 秒間加熱後の初期接着性はハイロン -5 を使用した接着 凰が 3.5 , トウモロコシ $(\mathrm{NaOH}, 0.5 \%)$ が 3.2 と若干高
かったが，馬鈴薯，甘藷，タピオカ，ワキシーでは 3.0 と なり，4 秒間あるいは 5 秒間加熱を含めても澱粉種による 大きな相違はなかった，ハイロン -5 とトウモロコシで若 干高かったが, Table 1 に示した弾性率や最大応力值との 明確な関係を示す結果とはならず，最も数值の低いワキ シーでも接着性の低下は大きくはなかった。結果として, 糊化膨潤澱粉の粒構造の有無や構造性の強さは, 初期接着 性には必ずしも反映しなかった。また，未剥離貼合サンプ ルの調湿後のピン接着強度は, 初期接着性の若干高い区が 特に高い結果とはならずに，Table 2 に示すように対象実 験区全てで $20 \mathrm{~kg} / 40 \mathrm{~cm}^{2}$ 以上の十分な接着強度を示した。 3-5 秒間加熱後の余熱による経時的な糊化の進行や糊化液 の浸透進行, さらには乾燥過程での糊化膨潤澱粉粒あるい は粒片とキャリヤー部澱粉との結合の進行強化などが考え られた。

このように初期接着性については, 弾性率の高さや最大 応力值, 粘度などのレオロジー物性測定值との関連がみら れなかったが，これには物性測定と初期接着性測定時の条 件の違いも影響していると考えられた。そこで, 初期接着 性を評価したテーブルテスト貼合剥離サンプルの接着郕凝 集破断部の状況を走査型電子顕微鏡にて観察した。

\section{SH 接着剤グルーラインの走査型電子顕微鏡観察}

キャリヤー部澱粉には全て糊化トウモロコシ澱粉水溶液 を使用した 7 種澱粉メイン部 SH 接着剂を用いて, 前項で の初期接着性の評価のために強制剥離した片段 (中芯 SCP-125) と表ライナーB-300 の SH 接着剂凝集破壞部を 走査型電子顕微鏡にて観察した。剥離したライナー部糊線 部の様子を Fig. 5，6に示す。

接着剂凝集破壊部の全般的な状況としては，実際のコル ゲーターのダブルフェーサーでの条件と同様に SH 接着剤 を片段に塗布して表ライナーと合せて表ライナーの表面側 から加熱を行っていることを反映して，ライナー裏面側の 接着剤凝集破壊部の方が中芯側の破壊部より糊化が進んで おり，澱粉粒形状の残存は少ない傾向にあった。また，凝 集破壞時に接着剂部が引きちぎられた形状を保持して破断 面に接着剂の突起が残り蜂の巣状を呈する場合と，その突 起がなく平坦な破断面を呈する場合とがあった。 

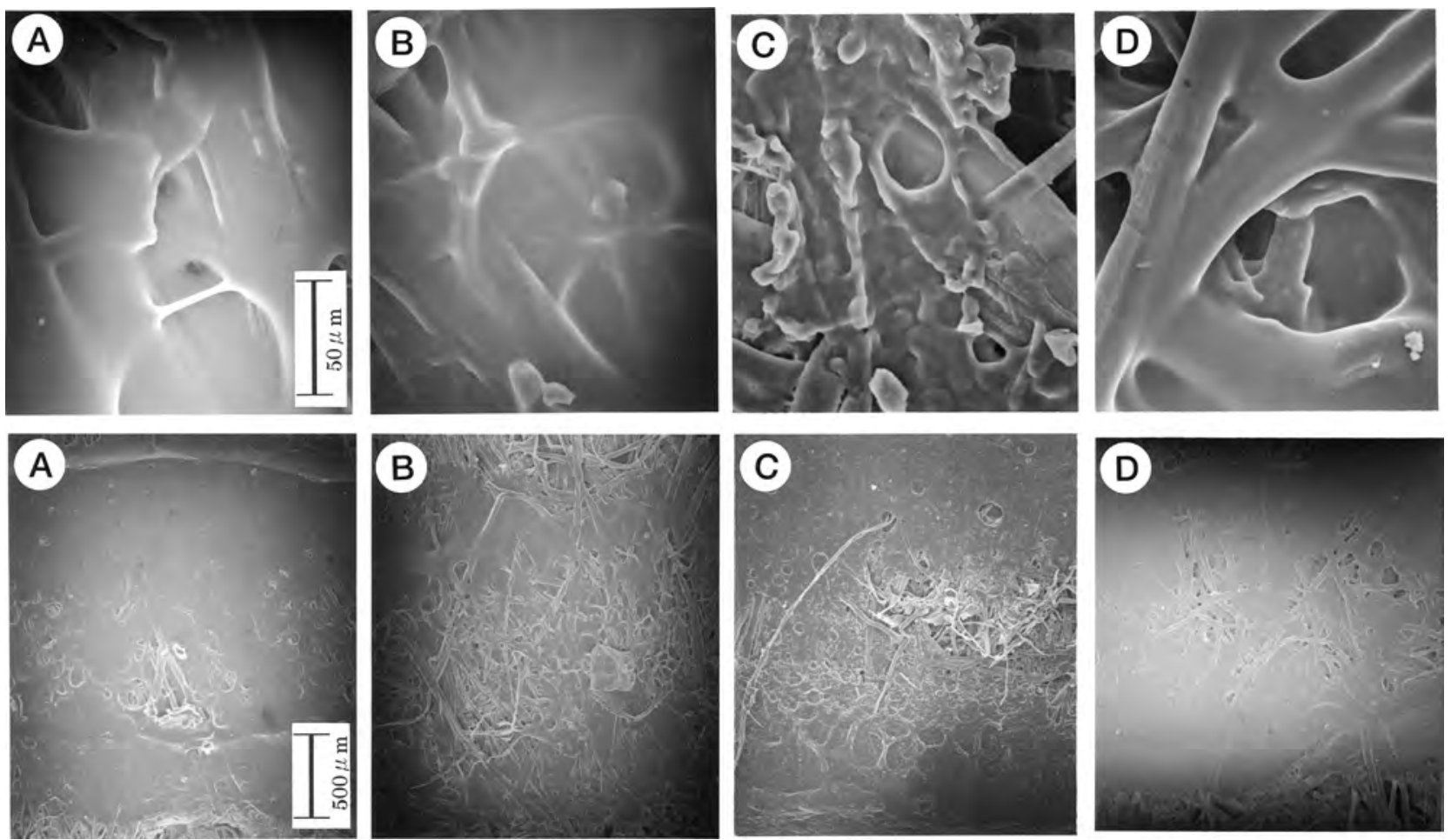

Fig. 5. Scanning electron micrographs of the $4 \mathrm{SH}$-adhesives glue lines immediately delaminated in the measurement of the green bond strength.

Micrographs A-D show each SH-adhesive glue line of corn, wheat, hylon-5 and waxy as main portion starch. (A), Corn NaOH $0.5 \%$; (B), Wheat $\mathrm{NaOH}$ 0.4\%; (C), Hylon-5 NaOH 0.75\%; (D), Waxy $\mathrm{NaOH} 0.5 \%$.
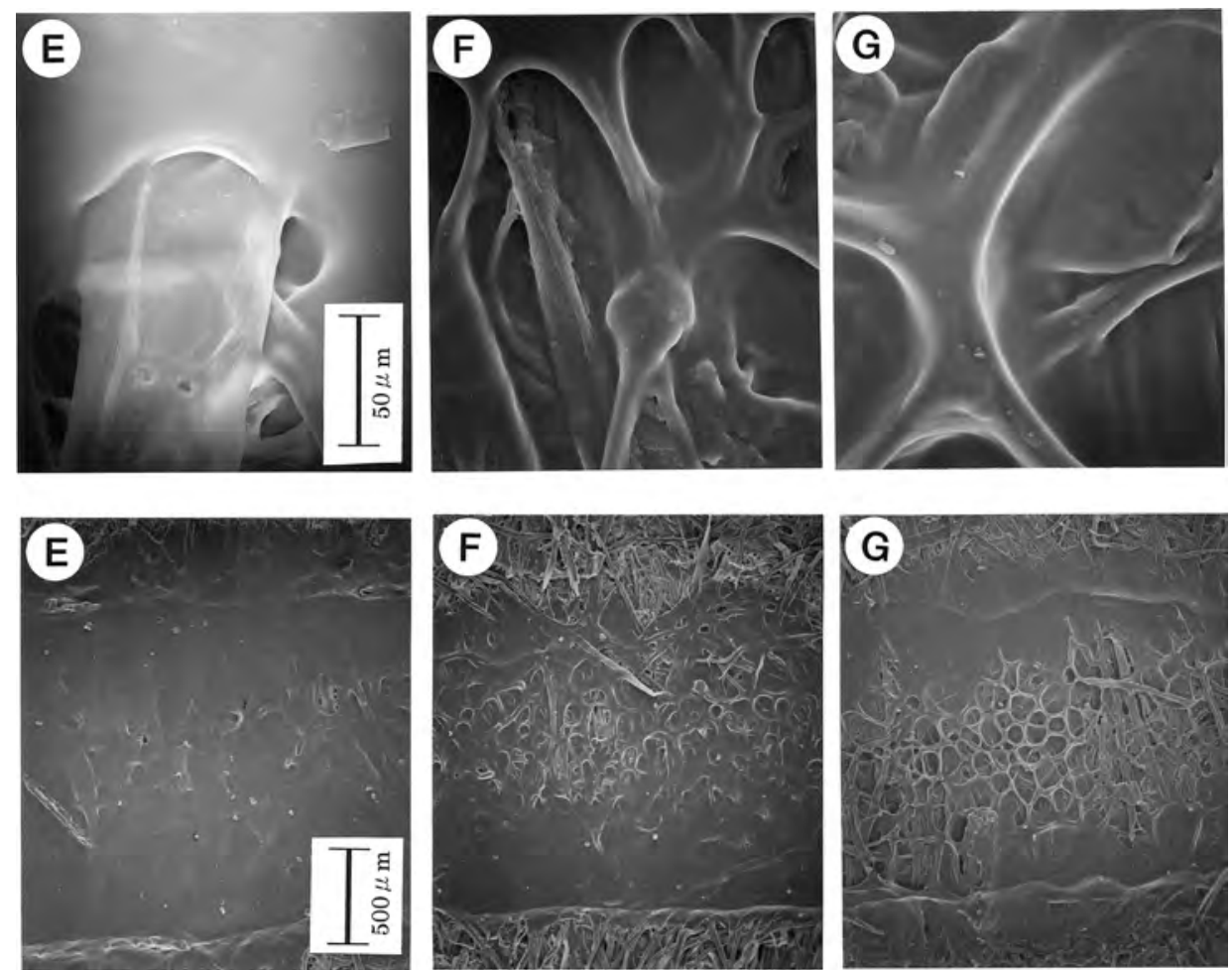

Fig. 6. Scanning electron micrographs of the $3 \mathrm{SH}$-adhesives glue lines immediately delaminated in the measurement of the green bond strength.

Micrographs E-G show each SH-adhesive glue line of potato, sweet potato and tapioca as main portion starch. (E), Potato $\mathrm{NaOH} 0.4 \%$; (F), Sweet potato $\mathrm{NaOH} 0.5 \%$; (G) Tapioca $\mathrm{NaOH} 0.5 \%$.

1 ) メイン部トウモロコシ澱粉または小麦澱粉

Fig. 5(A)と(B)に苛性ソーダ濃度 $0.5 \%$ のメイン部トウモ ロコシ澱粉 SH 接着剂と苛性ソーダ濃度 $0.4 \%$ のメイン部 小麦澱粉接着剤のそれぞれのライナー部凝集破壊部の電顕
写真を示す. $170^{\circ} \mathrm{C} て ゙ 3$ 秒間加熱後ただちに強制剥離して 初期接着性を確認した糊線部凝集破壊部は, トウモロコシ ではその約 $30 \%$ が小さな蜂の巣状を呈し, 残りの糊線部 は平坦化していた。 小麦では凝集破壊部の約半分が同様な 
蜂の巣状を呈していた。トウモロコシ，小麦共に糊線部全 体としては膨潤澱粉粒の融合が進み接着剂部の澱粉は一体 化していた。

2 ) メイン部ハイロン -5 澱粉

Fig. 5(C)に示すようにメイン部がハイロン-5 澱粉で苛性 ソーダ濃度 $0.75 \%$ の $\mathrm{SH}$ 接着剤では, $170^{\circ} \mathrm{C} 3$ 秒間加熱後 のライナー部糊線部凝集破壊部には膨潤程度が少ない澱粉 粒が多くみられ, 糊線部の大部分を占めていた. しかも糊 線部の半分以上は, トゥモロコシと同様な小さな蜂の巣状 を呈していたが，澱粉粒の融合は少なく破壊部に滑らかさ がなく突起した盛上りの程度は少なかった。

3 ) メイン部ワキシー澱粉

Fig. 5(D)に示すようにメイン部ワキシーの SH 接着剤で は, $170^{\circ} \mathrm{C} 3$ 秒間加熱後のライナー部接着剤凝集破壊部に は澱粉粒の痕跡は全くみられず，平坦化が進行していた。 平坦化の程度は他の澱粉種の場合よりも進行していた。

4 ) その他のメイン部澱粉の接着剂

Fig. 6(E)に馬鈴薯, Fig. 6(F)に甘藷, Fig. 6(G)にタピオ 力を示す. $170^{\circ} \mathrm{C} 3$ 秒間加熱後の接着剤凝集破壊部は, 馬 鈴薯では接着剤部に澱粉粒の痕跡がほとんどみられず，接 着剂部の平坦化はワキシーの場合と同等に進んでいた。糊 線端部には未糊化澱粉粒はみられなかったが, 澱粉粒の痕 跡がわずかにみられた。同様に, 甘藷と夕ピオカでは苛性 ソーダ濃度は $0.5 \%$ であるが, 接着剂凝集破壊部には澱粉 粒の痕跡はほとんどみられず, 澱粉粒の糊化は進んでい た。しかし，接着剤凝集破壊部は苛性ソーダ濃度 $0.4 \%$ の 小麦よりもやや大きな中位の泡からなる突起した蜂の巣状 に $50 \%$ 程度がなっており, 接着片破断面の突起の盛上り の程度は小麦やトウモロコシよりも大きかった。

電顕観察から, 明確な粒構造の残存はハイロン -5 での みみられ, SH 接着剤部の澱粉はライナー原紙を介する $170^{\circ} \mathrm{C}$ ホットプレートによるわずか 3 秒間の加熱において も, 八イロン -5 以外の澱粉では澱粉粒の膨潤糊化融合に よる一体化が進行していた，接着剤凝集破壊部の破断面は 馬鈴薯とワキシーでは平坦化が顕著であり，ハイロン -5 , 甘藷, タピオカ, トウモロコシと小麦では泡を噛んだ跡の ような蜂の巣状の破断面がみられ, ハイロン -5では破断

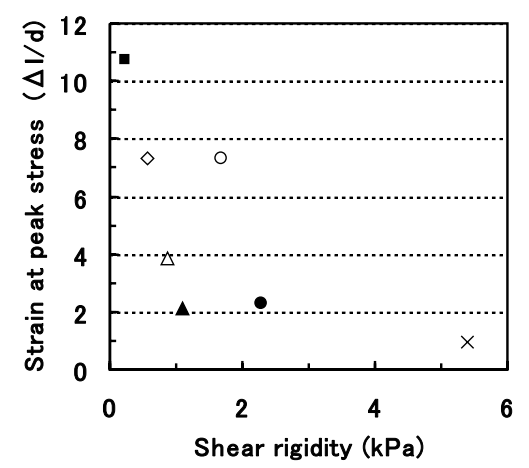

Fig. 7. Relation between rigidity and strain at peak stress of 7 starch pastes at $85^{\circ} \mathrm{C}$ from $\mathrm{SH}$-adhesives.

$\times$, Hylon-5; $\bullet$, Corn; $\Delta$, Wheat; $\boldsymbol{\square}$, Waxy; $\bigcirc$, Potato; $\triangle$, Sweet potato; $\diamond$, Tapioca.
面の盛上りの程度が少なく滑らかさも少なく, 甘諸と夕ピ オカではトウモロコシと小麦よりも盛上りの程度が大き かった。

Table 1 に示した 7 種澱粉をメイン部に使用した SH 接 着剤の糊化液の最大応力までのひずみ量を縦軸とし，せん 断弾性率を横軸として二つのパラメータで整理した関係困 を Fig. 7 に示す. 糊化液の流動性の指標を最大応力までの ひずみ量と考えると, ワキシーやタピオカや馬鈴薯の流動 性は高く, 電顕観察による糊線部凝集破壞部の平坦化との 関連が考えられた。しかしながら，Table 1 に示した最大 応力值や粘度值と接着剤凝集破壞部の状況との関連は見出 せなかった。

\section{要約}

トウモロコシ， ハイアミローストウモロコシ， ワキシー トウモロコシ, 小麦, 馬鈴薯, 甘諸, タピオカの 7 種澱粉 の $85^{\circ} \mathrm{C}$ 高濃度澱粉糊化液について, せん断ひずみ初期の せん断弾性率, 最大せん断応力值, せん断応力パターンと 粘度を測定した. 7 種澱粉懸濁液糊化液の物性は澱粉種に より大きく異なり，これら懸濁液糊化液と， 7 種の各澱粉 をメイン部に使用してキャリヤー部にトウモロコシ澱粉を 用いた $\mathrm{SH}$ 接着剂糊化液との $85^{\circ} \mathrm{C}$ での物性比較から, $\mathrm{SH}$ 接着剂糊化液物性はメイン部澱粉懸濁液糊化液物性を大き く反映し, キャリヤー部糊化澱粉水溶液の添加はせん断弾 性率や最大せん断応力值を高めた. また, 澱粉濃度の増加 により, $85^{\circ} \mathrm{C} 7$ 種澱粉懸濁液糊化液の各せん断弾性率とせ ん断最大応力值は指数関数的に増加した。さらに，糊化液 のせん断弾性率が表す弾性と最大応力までのひずみ量が表 す柔軟性や流動性は, 個々の澱粉種により澱粉濃度増加に よる変化が特徵的に異なった．弾性率が低く最大応力ひず み量が大きなワキシーと, 反対に弾性率が高く最大応力ひ ずみ量が少ない八イロン -5 と, その中間に位置する弾性 率がやや低く最大応力ひずみ量がやや大きな馬鈴薯・甘 藷・夕ピオカと, 弾性率がやや高く最大応力ひずみ量がや や少ない小麦・トウモロコシとの四つの異なるタイプに, 弾性率と最大応力ひずみ量との変化の違いにより明瞭に類 別された。このため SH 澱粉接着剂糊化液物性は使用する 澱粉種によりその物性が異なることがより明白となった。 弾性率は糊化澱粉粒の形状保持が良いハイロン -5 や地上 澱粉で高くなり, 最大応力までのひずみ量はワキシーや地 下澱粉で大きくなった. 実際のコルゲーターでの段ボール シート製造貼合時においても，SH 接着剤はスタティック に原紙を介して加熱され, 糊化濃縮乾燥されるため, 接着 剂糊化液は使用澱粉種に由来する膨潤粒の集合体としての 物性を基本的に保持していると考えられた。

また，キャリヤー部の効果としては，接着時の懸濁メイ ン部未糊化澱粉粒の吸水により濃縮されたキャリヤー部澱 粉が膨潤メイン部澱粉粒間に薄膜状に残留して, 膨潤澱粉 粒間の結合力を高め, せん断弾性率とせん断最大応力值が 
高くなった。また，傾向的には弾性率は澱粉糊化液の膨潤 澱粉粒構造の残存が多い場合に高くなり ${ }^{13)}$, 最大応力まで のひずみ量が大きい場合には柔軟性や流動性が高いと考え られた。

初期接着性評価で剥離した片段と表ライナーの接着剂凝 集破壊部の電子顕微鏡観察からは, 粒形がしっかり残って いるハイロン-5, 粒形の全く残っていないワキシーと，初 期接着時においても澱粉種により糊化状態は明瞭に異なっ ていた。しかしながら，これら糊化液物性の異なる 7 種澱 粉 SH 接着剂を用いた初期接着性には大きな相違はみられ なかったことから，初期接着性には澱粉接着剂糊化液の澱 粉粒構造の存在や弾性率の高さや最大応力值が最も優先す る条件ではなく，接着面積を拡大する流動性などの他の因 子とのバランスも重要と考えられた.

\section{文}

\section{献}

1 ) 日本スターチ・糖化工業会：日本スターチ・糖化工業会会 報, No. 7 (2007).

2 ) Stein Hall Manufacturing Company, J.V. Bauer: Method of making ply board, U.S.Patent 2,051,025 1936-8-18.

3 ) Stein Hall Manufacturing Company, J.V. Bauer: Plyboard adhesive, U.S.Patent 2,102,937 1937-12-21.

4 ) Stein Hall Manufacturing Company, J.V. Bauer: Composition adapted for use as an adhesive, U.S.Patent 2,212,557 1940-827.

5 ) Stein Hall Manufacturing Company, J.V. Bauer: Improvement in method of manufacturing corrugated paper board, U.K.Patent 466,062 1937-5-21

6 ) 渋谷新四郎，高橋礼治：段ボール用接着剤としての澱粉に ついて. 段ボールの技術，(4)，2-8 (1961).

7 ) 高橋礼治：澱粉系段ボール接着剂の流動特性．段ボール， (10), 40-45 (1965).

8 ) 高橋礼治：澱粉系接着剂の当面する課題. 段ボール，(1), 31-34 (1967).

9 ) 吹野弘武：デンプンと段ボール製造. J. Appl. Glycosci., 47, $73-85$ (2000).

10) R.H. Williams, C.H. Leak and M.A. Silano: Influence of carrier starch on green bond strength in corrugating adhesive. TAPPI, 60 (4), 86-89 (1977).

11) 高橋礼治, 山本正樹 : 苛性ソーダ中におけるデンプンの挙 動. 澱粉工誌，17，289-293 (1969).

12) John Reinholz: New starch system helps corrugator run faster. BOXBOARD CONTAINERS, (9), 50-52 (1977).

13）高橋礼治，小林信夫，山本正樹：カードメーターによるデ ンプンゲルの破壊強度について．澱粉工誌，16，139-143 (1969).
数種の段ボール製造用スタインホール型澱粉接着剤 高温糊化液物性について

小役丸孝俊

レンゴー株式会社中央研究所

(553-0007 大阪市福島区大開 4-1-186)

メイン部とキャリヤー部からなるいわゆるスタインホー ル型 (SH) 段ボール製造用澱粉接着剂の高速接着時の必要 物性を明確にするために， $85^{\circ} \mathrm{C}$ で高濃度澱粉糊化液のせ 几断ひずみ初期のせん断弾性率，最大せん断応力值，せん 断応力パターンと粘度をトウモロコシ，八イアミロースト ウモロコシ (ハイロン-5)，ワキシートウモロコシ，小麦， 馬鈴薯，甘藷，タピオカの 7 種の澱粉について測定した. 7 種澱粉懸濁液糊化液の物性は澱粉種により大きく異な り, これら懸濁液糊化液と, 7 種の各澱粉をメイン部に使 用してキャリヤー部にトウモロコシを用いた SH 接着郕糊 化液との $85^{\circ} \mathrm{C}$ での物性比較から, $\mathrm{SH}$ 接着剤の糊化液物性 はメイン部澱粉懸濁液糊化液物性を大きく反映し，キャリ ヤー部糊化澱粉水溶液の添加はこれらの物性を増強した。 せん断弾性率と最大せん断応力值は澱粉種により差異が あった。また，澱粉濃度の増加により， $85^{\circ} \mathrm{C} 7$ 種澱粉懸濁 液糊化液の各せん断弾性率と最大せん断応力值は指数関数 的に増加した。さらに，糊化液のせん断弾性率が表す弾性 と最大応力までのひずみ量が表す柔軟性や流動性は個々の 澱粉種により澱粉濃度増加による変化が特徵的に異なり, 四つのタイプに分類された。弾性率が高い順序と最大応力 までのひずみ量が小さな順序で整理すると，弾性率が高く 最大応力までのひずみ量が少ないハイロン -5 と, 弾性率 がやや高く最大応力までのひずみ量がやや少ない小麦・卜 ウモロコシと，弾性率がやや低く最大応力までのひずみ量 がやや大きな馬鈴著・甘諸・夕ピオカと, 弾性率が低く最 大応力までのひずみ量の大きなワキシーと異なる四つの夕 イプに分類された。その結果，SH 澱粉接着剂糊化液物性 は使用する澱粉種によりその物性が異なることがより明白 となった。また，弾性率は糊化澱粉粒の形状保持が良い八 イロン -5 や地上澱粉で高くなり，最大応力までのひずみ 量はワキシーや地下澱粉で大きくなった。しかしながら， 7 種澱粉をメイン部に用いる SH 接着郕にて片段試料と表 ライナー原紙を $170^{\circ} \mathrm{C}$ のホットプレートで加熱貼合して, ただちに剥離した際の初期接着性には，澱粉種による大き な相違はなかった。これらのことから，初期接着性には澱 粉接着剂糊化液の澱粉粒構造の存在や弾性率の高さや最大 応力值が最も優先する条件ではないと考えられた。 